\title{
RANCANG BANGUN ROBOT SAR SEBAGAI PENDETEKSI GAS BERACUN PRA EVAKUASI
}

\author{
Bima Renaldi, Suryo Adi Wibowo, Karina Auliasari \\ Program Studi Teknik Informatika S1, Fakultas Teknologi Industri \\ Institut Teknologi Nasional Malang, Jalan Raya Karanglo km 2 Malang, Indonesia \\ 1618058@scholar.itn.ac.id
}

\begin{abstract}
ABSTRAK
Penelitian ini dilakukan untuk membuat dan merancang sebuah robot SAR sebagai pendeteksi gas beracun pra evakuasi untuk memeriksa keadaan pada tempat yang akan dilaksanakan evakuasi untuk keamanan dari tim penyelamat dan memperoleh infomasi terbaru dari tempat kejadian. Hal ini juga bertujuan untuk meminimalisir jatuhnya korban pra evakuasi seperti pada Tim SAR ataupun tim penyelamat lainnya khususnya diwilayah urban atau perkotaan. Robot pendeteksi gas ini dapat melakukan atau menampilkan hasil monitoring dari kadar kandungan gas disekitarnya lewat website. Disamping itu dengan kontrol yang bisa dilakukan lewat website akan membuat sistem robot menjadi lebih efisien dan efektif. Dari Hasil pengujian menunjukkan bahwa sensor diketahui memiliki rata-rata persentase error pada sensor MQ-7 sebesar 6,54\%, Sensor MQ-135 sebesar 19,08\% untuk deteksi gas Amonia dan 3,16\% untuk Karbon Dioksida, serta 9,83\% untuk sensor ultrasonic. . Jarak terjauh flame sensor untuk mendeteksi api secara optimal yaitu pada jarak $80 \mathrm{~cm}$ dengan nilai voltage $1.74 \mathrm{v}$ dan tidak dapat lagi pendeteksi api pada jarak $84 \mathrm{~cm}$ dengan nilai voltage $2.03 \mathrm{v}$ Robot SAR dapat beroperasi optimal selama 40 Menit. Website berjalan dengan baik pada beberapa web browser yang diujikan yaitu Mozila Firefox (47.0.2), Google Chrome (78.0.3) dan Microsoft Edge (44.1.0) karena aplikasi merupakan website responsive yang dibuat menggunakan pemrograman PHP. Metode Fuzzy Tsukamoto dapat berjalan dengan baik dan akurat pada sistem dengan rata - rata persentase error $0 \%$.
\end{abstract}

Kata kunci : Embedded system, Robot Pendeteksi Gas, Metode Fuzzy Tsukamoto, Arduino Uno, NodeMCU.

\section{PENDAHULUAN}

Dalam perkembangan teknologi robot saat ini, banyak dikembangkan robot pendeteksi gas. Hal ini tentunya sangat membantu berbagai pihak mulai perorangan ataupun perusahaan besar untuk mendeteksi gas - gas berbahaya di tempat - tempat yang tidak bisa dijangkau oleh manusia. Hal ini juga bertujuan untuk meminimalisir jatuhnya korban pra evakuasi seperti pada Tim SAR ataupun tim penyelamat lainnya khususnya diwilayah urban atau perkotaan.Terdapat beberapa resiko bagi regu sar saat melakukan evakuasi seperti struktur bangunan yang rumit dan sulit diakses, adanya resiko gedung yang akan runtuh, serta tersebarnya kandungan gas beracun akibat sistem ventilasi udara pada gedung yang bermasalah.

Banyak robot telah dilengkapi oleh berbagai jenis sensor untuk mendeteksi gas seperti MQ-2 untuk mendeteksi gas LPG yang bocor, Sensor MQ4 untuk mendeteksi gas metana dan $\mathrm{CNG}$, sensor MQ-7 untuk mendeteksi gaskarbon monoksida (CO), dan seterusnya. Namun pada pengembangan robot beberapa komponen tidak digunakan secara maksimal. Contoh penggunaan modul ESP8266 yang hanya dijadikan sebagai pembantu kontrol jarak jauh padahal bisa digunakan pula untuk melakukan monitoring lewat website. Media monitoring data pada robot juga terbatas hanya menggunakan led dan buzzer bila gas berbahaya terdeteksi ataupun LCD untuk menampilkan kadar kandungan gas dari sekitar robot yang dirasa kurang efektif dan fleksible.

Untuk itulah dikembangkan robot pendeteksi gas yang dapat melakukan atau menampilkan hasil monitoring dari kadar kandungan gas disekitarnya lewat website. Disamping itu dengan kontrol yang bisa dilakukan lewat website akan membuat sistem robot menjadi lebih efisien dan efektif. Dengan adanya fitur tersebut user atau pengendali akan dimudahkan dalam mengendalikan mobilisasi robot serta dapat dengan mudah memonitoring kadar kandungan gas tanpa perlu repot-repot melihat langsung pada LCD Robot.

\section{TINJAUAN PUSTAKA}

Ditahun 2019 Wibowo dkk mengembangkan ruang kuliah pintar pemantau tingkat efektifitas pembelajaran yang dapat mendeteksi mahasiswa bosan dan mengantuk. Alat ini dapat mendeteksi kebosanan atau rasa kantuk pada mahasiswa melalui ekspresi wajah yang diambil oleh kamera lalu diolah dengan proses pengolahan citra digital. Selain mendeteksi kebosanan mahasiswa, alat ini juga dilengkapi dengan sistem presensi menggunakan RFID. Mahasiswa yang melakukan presensi dengan RFID datanya di kirimkan pada mikrokontroler lalu dengan bantuan modul ethernet EG-SR-7150MJ sebagai penghubung antara mikro kontroler dan jaringan internet sehingga data dapat disimpan pada server dan ditampilkan lewat website yang dapat diakses oleh pengajar, mahasiswa dan orangtua.[1] 
Sebelumnya di tahun 2017 Liandy mengembangkan pemantau gas berbahaya dan suhu pada ruangan melalui website berbasis arduino. Alat ini menggunakan sensor MQ-2 untuk mendeteksi adanya kadar gas LPG, sensor MQ-7 untuk mendeteksi kadar karbon monoksida (CO) serta sensor DHT11 untuk mengukur suhu diruangan serta sensor flame detector untuk mendeteksi kebakaran. Data dari sensor -sensor tersebut secara berkala ditampilkan lewat website dengan bantuan arduino dan modul wifi esp8266. Jika pada ruangan tersebut terdeteksi api maka water pump akan menyala dan memadamkan api kemudian mengirim email pemberitahuan pada pengguna jika terjadi kebakaran agar pengguna dapat memantau keadaan ruangan lewat ipcam yang terhubung dengan website [2]

\subsection{Fuzzy Tsukamoto}

Menurut Kusumadewi pada tahun 2010 metode Tsukamoto merupakan perluasan dari penalaran monoton. Pada metode Tsukamoto, setiap konsekuen pada aturan yang berbentuk IF-Then harus dipresentasikan dengan suatu himpunan fuzzy dengan fungsi keanggotaan yang monoton. Sebagai hasilnya, output hasil inferensi dari tiap-tiap aturan diberikan secara tegas (crisp) berdasarkan $\alpha$ predikat (fire strength). Hasil akhirnya diperoleh dengan menggunakan rata-rata terbobot.[3] Fungsi keanggotannya antara lain :

NH3 $\{$ rendah $=0$; Tinggi $=25\}$

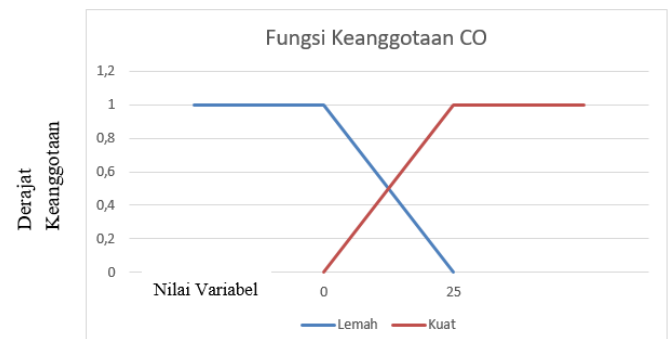

Gambar 1 Fungsi keanggotaan Gas Amonia (NH3) $\mathrm{CO}\{$ lemah $=0 ;$ kuat $=25\}$

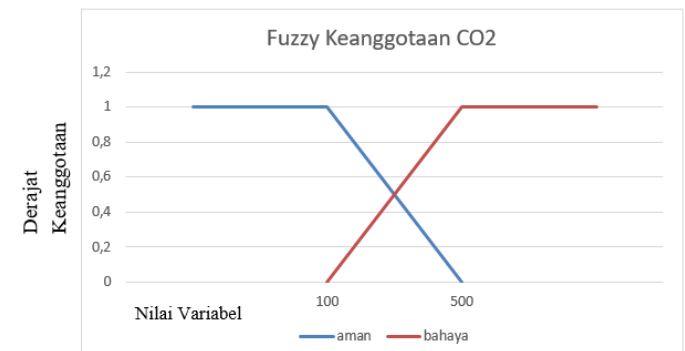

Gambar 2 Fungsi keanggotaan Gas Karbon Monoksida (CO)

$\mathrm{CO} 2\{$ aman=100; bahaya $=500\}$

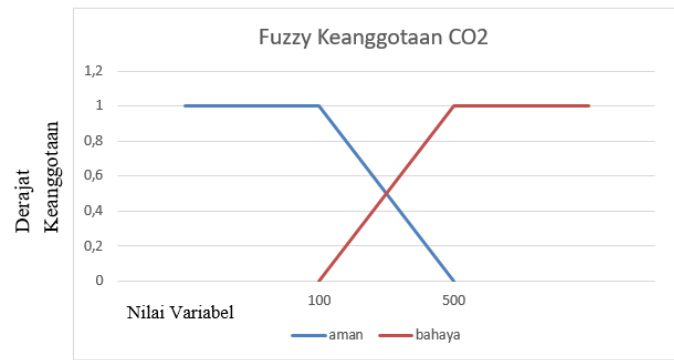

Gambar 3 Fungsi keanggotaan Gas Karbon Dioksida $(\mathrm{CO} 2)$

Langkah -langkah Metode

a. Arduino menerima inputan data dari sensor MQ-7 dan MQ-135 untuk kandungan gas disekitar robot

b. MQ-7 mendeteksi kadar karbon monoksida dan MQ-135 mendeteksi kadar amonia.

c. Kedua data dari MQ-7 dan MQ-135 di fuzzifikasi sehingga menghasilkan nilai keanggotaan. Untuk MQ-7 \{lemah, kuat\} dan untuk MQ-135\{rendah, tinggi\}. Kemudian ditemukan juga untuk klasifikasi \{bahaya, aman\}

d. Setelah mendapat hasil dari fuzzifikasi lalu dilakukan operasi interfensi tsukamoto dengan rule

[R1] Jika MQ-7 lemah dan MQ-135 rendah maka klasifikasi Aman

[R2] Jika MQ-7 lemah dan MQ-135 tinggi maka klasifikasi Bahaya

[R3] Jika MQ-7 kuat dan MQ-135 rendah maka klasifikasi Bahaya

[R4] Jika MQ-7 kuat dan MQ-135 tinggi maka klasifikasi Bahaya

e. Untuk tahap interfensi tsukamoto pertama dilakukan pencarian nilai a_predikat dengan nilai minimal. Kemudian dilakukan perhitungan untuk mencari $\mathrm{z}$ dengan perhitungan $\mathrm{z}=$ a_predikat $*$ (aman- bahaya $)+$ aman

f. Setelah hasil [R1] - [R4] ditemukan, maka dilakukan proses defuzzifikasi

\subsection{IoT (Internet Of Think)}

IoT merupakan Sebuah konsep dimana suatu objek yang memiliki kemampuan untuk mentransfer data melalui jaringan tanpa memerlukan interaksi manusia ke manusia atau manusia ke komputer Penggunaan IoT dapat diimplementasikan pada berbagai hal salah satunya adalah perkuliahan., pelanggan, dan sebagainya yang dapat diakses dari basis data perusahaan.[4]

\subsection{Arduino Uno}

Arduino Uno adalah board mikrokontroler yang di dalamnya terdapat mikrokontroler, penggunaan jenis mikrokontroler-nya berbeda - beda tergantung spesifikasinya. Pada Arduino Uno diguanakan mikrokontroler berbasis ATmega328. Memiliki 14 pin input dari output digital dimana 6 pin input 
tersebut dapat digunakan sebagai output PWM dan 6 pin input analog, $16 \mathrm{MHz}$ osilator kristal, koneksi USB, jack power, ICSP header, dan tombol reset.[2]

\subsection{Model ESP8266}

ESP8266 adalah chip terintegrasi yang di rancang untuk kebutuhan terhubungnya dunia. Ia menawarkan solusi jaringan wifi yang lengkap dan mandiri, yang memungkinkan untuk menjadi host atau mentranfer semua fungsi jaringan wifi dan prosesor aplikasi lain dengan ATcommand sebagai perintah dasarnya. ESP8266 memiliki kemampuan pengolahan dan penyimpanan on-board yang kuat, yang memungkinkan untuk diintegrasikan dengan sensor dan aplikasi perangkat khusus lain melalui GPIOs dengan pengembangan yang mudah loading waktu yang minimal. [5]

\subsection{Sensor MQ-7}

MQ 7 merupakan sensor gas yang digunakan dalam peralatan untuk mendeteksi gas karbon monoksida (CO) dalam kehidupan seharihari, industri, atau mobil. Fitur dari sensor gas MQ7 ini adalah mempunyai sensitivitas yang tinggi terhadap karbon monoksida (CO), stabil, dan berumur panjang. Sensor ini menggunakan catu daya heater : 5V AC/DC dan menggunakan catu daya rangkaian : 5VDC, jarak pengukuran : 20 2000ppm untuk ampu mengukur gas karbon monoksida.[6]

\subsection{Sensor MQ-135}

MQ-135 Air Quality Sensor adalah sensor yang memonitor kualitas udara untuk mendeteksi gas amonia (NH3), natrium-(di)oksida (NOx), alkohol / ethanol $(\mathrm{C} 2 \mathrm{H} 5 \mathrm{OH})$, benzena (C6H6), karbondioksida (CO2), gas belerang / sulfurhidroksida (H2S) dan asap / gas-gas lainnya di udara. Sensor ini melaporkan hasil deteksi kualitas udara berupa perubahannilai resistensi analog di pin keluarannya. Pin keluaran ini bisa disambungkan dengan pin 6ADC (analog-to-digital converter) di mikrokontroler / pin analog input Arduino denganmenambahkan satu buah resistor saja (berfungsi sebagai pembagi tegangan / voltage divider).[7]

\subsection{Sensor Ultrasonic}

SRF (Sensor Ultrasonik) adalah sebuah sensor yang berfungsi untuk mengubah besaran fisis (bunyi) menjadi besaran listrik dan sebaliknya. Cara kerja sensor ini didasarkan pada prinsip dari pantulan suatu gelombang suara sehingga dapat dipakai untuk menafsirkan eksistensi (jarak) suatu benda dengan frekuensi tertentu. Disebut sebagai sensor ultrasonik karena sensor ini menggunakan gelombang ultrasonik (bunyi ultrasonik).[8]

\subsection{NodeMCU}

NodeMCU merupakan salah satu bagian dari keluarga ESP8266 yang sudah dibekali komponen pendukung yang lengap. Berbeda dengan modul sebelumnya ESP-01 yang hanya chip saja tanpa dilengkapi usb uart, modul ini sudah dilengkapi dengan minimum sistem serta usb uart yang memudahkan kita untuk menggunakan dan memasukan program pada modul tersebut.Dengan beragam kelebihan tersebut membuat modul ini sangat cocok sebagai mikrokontroler system IoT (Internet of Thing). Perangkat NodeMCU generasi ketiga ini sebenarnya bukan official dari ESP8266, ini hanya versi modifikasi yang di kembangkan oleh produsen LoLin dengan beberapa perbaikan yang membuat perangkat ini di claim lebih cepat dari versi sebelumnya. [9]

\subsection{Flame Detector}

Flame Detector atau Flame sensor merupakan sensor yang mempunyai fungsi sebagai pendeteksi nyala api yang memiliki panjang gelombang antara $760 \mathrm{~nm}-1100 \mathrm{~nm}$. Sensor ini menggunakan infrared sebagai tranduser dalam mensensing kondisi nyala api. Cara kerja sensor ini yaitu dengan mendeteksi nyala api dengan menggunakan metode optik. Pada sensor ini menggunakan tranduser yang berupa infrared (IR) sebagai sensing sensor. Tranduser ini digunakan untuk mendeteksi akan penyerapan cahaya pada panjang gelombang tertentu.[2]

\section{METODE PENELITIAN}

Penelitian ini akan membahas mengenai perancangan dan pembuatan robot SAR sebagai pendeteksi gas beracun pra evakuasi

\subsection{Analisa Kebutuhan Fungsional}

Adapun beberapa kebutuhan fungsional dalam rancang bangun robot SAR sebagai pendeteksi gas beracun pra evakuasi dapat dilihat pada Tabel 1 .

Tabel 1.Kebutuhan Fungsional

\begin{tabular}{|c|l|l|}
\hline No. & \multicolumn{1}{|c|}{ Hardware } & \multicolumn{1}{|c|}{ Software } \\
\hline 1 & Arduino Uno R3 & $\begin{array}{l}\text { Arduino IDE } \\
6.11\end{array}$ \\
\hline 2 & Modul ESP8266 & Notepad ++ \\
\hline 3 & NodeMCU v3 & XAMPP \\
\hline 4 & $\begin{array}{l}\text { Sensor Gas MQ-7 } \\
\text { (Pendeteksi Karbon } \\
\text { Monoksida) }\end{array}$ & Web browser \\
\hline 5 & $\begin{array}{l}\text { Sensor Gas MQ-135 } \\
\text { (Pendeteksi Amonia dan } \\
\text { Carbon Moniksida) }\end{array}$ & - \\
\hline 6 & Sensor Ultrasonic & - \\
\hline 7 & Motor DC 12v & - \\
\hline 8 & Driver Motor L298N & - \\
\hline 9 & Motor Servo & - \\
\hline 10 & Limit Switch & - \\
\hline
\end{tabular}




\subsection{Diagram Blok Sistem Monitoring Robot}

Sistem monitoring pada robot menggunakan mikrokontroler arduino uno $\mathrm{r} 3$ sebagai pusat kontrol dan pengelola data. Data kadar Karbon monoksida (CO) dari sensor MQ-7, data kadar amonia (NH3) serta data jarak dari sensor ultrasonic dikirim lalu diolah oleh arduino uno. Lalu diteruskan lewat modul ESP8266 data disimpan ke database dan dapat ditampilkan lewat website sehingga dapat dilihat oleh user. Blok diagram sistem monitoring dapat dilihat pada Gambar 4.

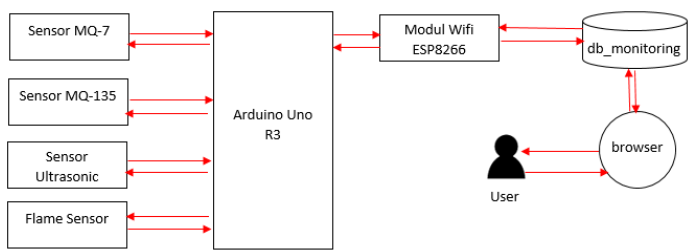

Gambar 4 Diagram blok sistem monitoring pada robot

\subsection{Diagram Blok Sistem Kontroling Robot}

Sistem kontrol pada robot menggunakan NodeMCU sebagai pusat kontrol dan pemroses data. User dapat menekan keyboard saat mengakses website pada browser untuk bisa mengirim perintah spesifik pada NodeMCU yang nantinya akan menggerakkkan Motor Dc dengan bantuan driver motor L298N dan motor servo untuk mengendalikan mobiltas robot. Kemudian Limit switch berfungsi untuk menghentikan dan memundurkan robot untuk bergerak saat robot menabrak sesuatu di didepannya disaat terjadi kegagalan sistem atau terputusnya koneksi sehingga motor tidak terus bergerak dan terbakar

Blok diagram sistem kontroling dapat dilihat pada Gambar 5 .

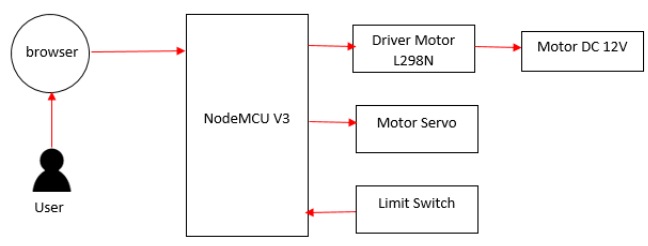

Gambar 5 Diagram blok sistem monitoring pada robot

\subsection{Alokasi Pin}

Alokasi pin untuk sistem kontroling robot bisa dilihat pada Tabel 2

Tabel 2. Alokasi pin sistem kontroling robot

\begin{tabular}{|l|l|c|c|c|}
\hline NodeMCU & $\begin{array}{c}\text { Driver Motor } \\
\text { L298N }\end{array}$ & $\begin{array}{c}\text { Motor Servo } \\
1\end{array}$ & $\begin{array}{c}\text { Limit } \\
\text { Switch 1 }\end{array}$ & $\begin{array}{c}\text { Limit } \\
\text { Switch 1 }\end{array}$ \\
\hline Vin 5V & VCC & VCC & VCC & VCC \\
\hline GND & GND & GND & GND & GND \\
\hline D2/GPIO5 & IN A.1 & - & - & - \\
\hline D3/GPIO4 & IN A.2 & - & - & - \\
\hline D4/ GPIO0 & IN A.3 & - & - & - \\
\hline D5/GPIO2 & IN A.4 & - & - & - \\
\hline D6/GPIO14 & - & DATA & - & - \\
\hline D7/GPIO12 & - & - & DATA & - \\
\hline D8/GPIO11 & - & - & - & DATA \\
\hline
\end{tabular}

Semua komponen menggunakan $v c c 5 \mathrm{v}$ dan ground.Driver motor menggunakan pin 5 dan 4 untuk kendali motor A dan pin 0 dan 2 untuk kendali motor B. Kemudian Motor servo memggunakan pin 14 untuk kendali motor. Kemudian limit switch 1 menggunakan pin 12 dan limit switch 2 menggunakan pin 11 sebagai pin data.

Kemudian untuk Alokasi pin sistem monitoring dapat dilihat pada Tabel 3 .

Tabel 3. Alokasi pin sistem monitoring robot

\begin{tabular}{|l|c|c|c|c|c|c|}
\hline $\begin{array}{c}\text { Arduin } \\
\text { o Uno }\end{array}$ & $\begin{array}{c}\text { ESP826 } \\
6\end{array}$ & $\begin{array}{c}\text { MQ- } \\
7\end{array}$ & $\begin{array}{c}\text { MQ- } \\
135\end{array}$ & $\begin{array}{c}\text { Ultrasonic } \\
1\end{array}$ & $\begin{array}{c}\text { Ultrasonic } \\
2\end{array}$ & $\begin{array}{c}\text { Flame } \\
\text { Detecto } \\
\mathrm{r}\end{array}$ \\
\hline VCC & VCC & VCC & VCC & VCC & VCC & VCC \\
\hline GND & GND & $\begin{array}{l}\text { GN } \\
\text { D }\end{array}$ & $\begin{array}{l}\text { GN } \\
\text { D }\end{array}$ & GND & GND & GND \\
\hline Pin 3 & Rx & - & - & - & - & - \\
\hline Pin 4 & Tx & - & - & - & - & - \\
\hline Pin 6 & - & - & - & Trig & - & - \\
\hline Pin 7 & - & - & - & Echo & - & - \\
\hline Pin 8 & - & - & - & - & Trig & - \\
\hline Pin 9 & - & - & - & - & Echo & - \\
\hline Pin A0 & - & - & Data & - & - & - \\
\hline Pin A1 & - & Data & - & - & - & - \\
\hline Pin A2 & - & - & - & - & - & Data \\
\hline
\end{tabular}

Semua komponen menggunakan vcc $5 \mathrm{v}$ dan ground. Esp8266 menggunakan pin 3 dan 4 untuk pin penerima dan pengirim data ke website. Mq-7 menggunakan pin A1 sebagai pin data, Mq-135 menggunakan A0 sebagai pin data, flame sensor menggunakan pin A2, sebagai pin data. Sensor Ultrasonic menggunakan pin 6 untuk mengirim gelombang dan pin $\quad 7 \quad$ untuk menerimanya. Begitu pula pada Ultrasonic 2 menggunakan pin 8 untuk mengirim gelombang dna pin 9 untuk menerimanya

\subsection{Struktur Menu Website}

Website monitoring pada robot terdiri dari tiga halaman utama yaitu halaman kendali, data, dan grafik.Berikut stuktur menu pada website dapat dilihat pada Gambar 6.

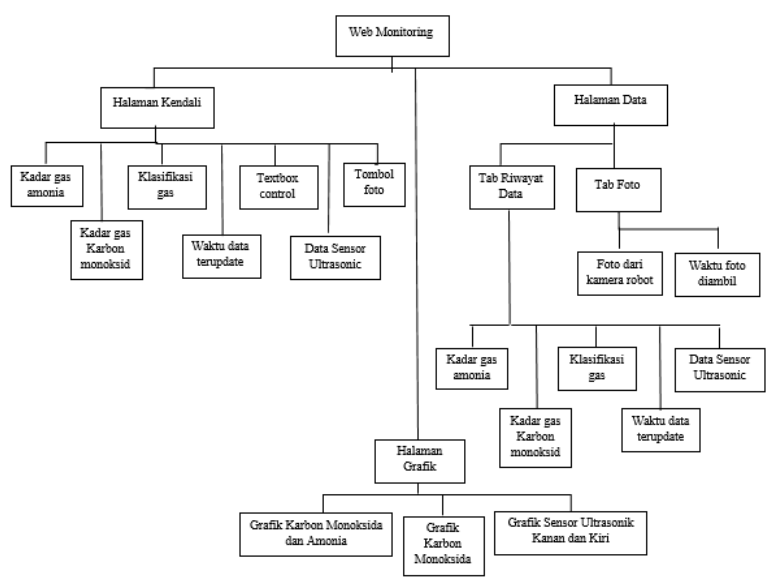

Gambar 6. Struktur menu website 


\subsection{Desain Arsitektur Metode}

Desain arsitektur metode menjelaskan alur dari perhitungan fuzzy tsukamoto yang digunakan untuk proses klasifikasi gas pada robot. Flowchart metode bisa dilihat pada Gambar 7.

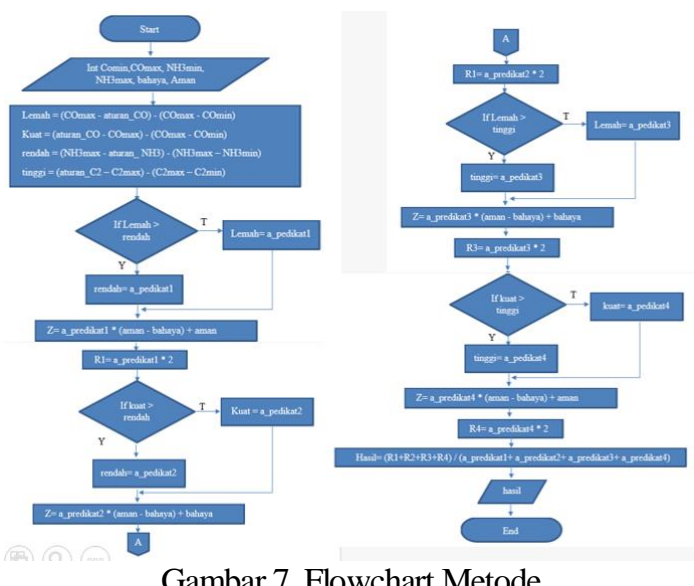

Alur flowchart pada gambar 7 dilakuakan proses perhutangan fuzzy tsukamoto. Pertama dilakukan deklarasi variabel untuk kandungan $\mathrm{NH} 3$ dan $\mathrm{CO}$, kemudian mengambil nilai input dari sensor mq-7 (CO) dan mq-135. Kemudian dilakukan proses peritungann himpunan fuzzy. Setelah didapatkan a predikat maka selanjutnya dilakukan inferensi tsukamoto untuk mencari nilai $\mathrm{z}$ dari setiap variabel dengan rule yang telah ditentukan. Setelah proses inferensi selesai maka dilakukan proses defuzzifikasi yang hasilnya akan dikrim ke website dan disimpan di database.

\subsection{Desain Arsitektur Sistem}

Desain arsitektur sistem menjelaskan alur dari berjalannya sistem monitoring dan kontroling pada robot. Flowchart sistem bisa dilihat pada Gambar 8 .

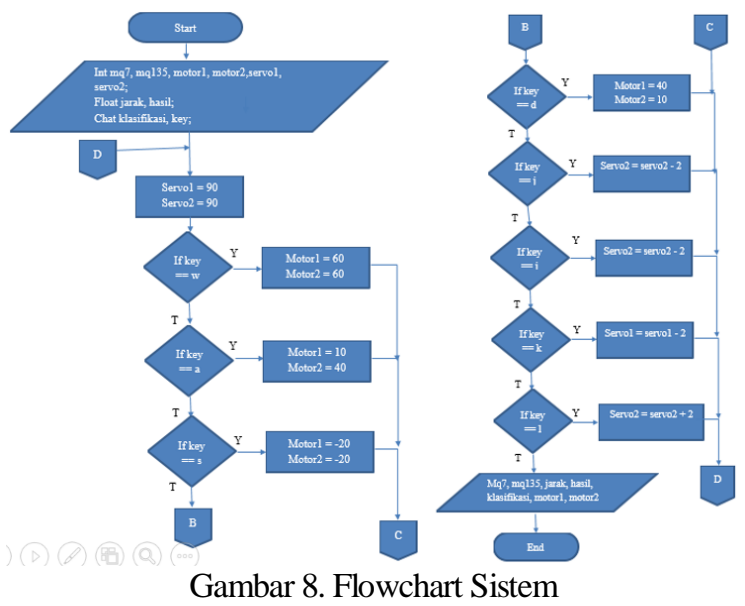

Pada Gambar 8 dapat dilihat bahwa alur pertama yaitu mendeklarasikan berbagai variabel yang diperlukan seperti nilai sensor mq-7, mq-135, jarak dan hasil dalam bentuk float. Flame sensor, motor motor1, motor2, dan servo1 sebagai integer dan klasifikasi dan key sebagai char. Servo pada awalnya servo1 bernilai 90 agar kamera menghadap kedepan. Jika key yang yang diinputkan w, maka motor 1 dan 2 akan berjalan maju. Jika diinputkan a, maka motor1 akan berjalan dan motor2 berhenti sehingga robot akan berbelok ke kiri. Jika s diinputkan maka robot akan berhenti. Dan jika diinputkan d maka motor1 akan berhenti dan motor2 akan berjalan sehingga akan berbelok ke kanan. Jika diinputkan j maka servo akan bernilai 0 sehingga menghadap ke kiri. Jika i diinputkan maka servo akan bernilai 90 sehingga menghadap ke depan. Jika 1 diinputkan maka servo akan bernilai 180 sehingga menghadap ke kanan. Kemudian semua data dari sensor akan ditampilkan pada website sehingga dapat dilihat dan diamati oleh user.

\section{HASIL DAN PEMBAHASAN}

Pada bab ini akan ditunjukkan hasil dan pembahasan terhadap proses yang telah dilakukan.

\subsection{Pengujian Metode Fuzzy Tsukamoto}

Hasil pengujian dilakukan dengan membandingkan hasil perhitungan manual metode Fuzzy Tsukamoto dengan hasil perhitungan pada sistem klasifikasi. Penggujian ditunjukkan pada Tabel 4.

Tabel 4. Pengujian metode fuzzy tsukamoto

\begin{tabular}{|l|c|c|c|c|c|}
\hline No. & $\begin{array}{c}\text { Nilai } \\
\text { NH3 }\end{array}$ & $\begin{array}{c}\text { Nilai } \\
\text { Co }\end{array}$ & $\begin{array}{c}\text { Hasil } \\
\text { Perhitungan } \\
\text { Manual }\end{array}$ & $\begin{array}{c}\text { Hasil } \\
\text { Perhitungan } \\
\text { pada sistem }\end{array}$ & $\begin{array}{c}\text { Persentase } \\
\text { error }\end{array}$ \\
\hline 1. & 25 & 10 & 308 & 308 & $0 \%$ \\
\hline 2. & 0.2 & 2.35 & 137.05 & 137.05 & $0 \%$ \\
\hline 3. & 0.1 & 1.68 & 128.67 & 128.67 & $0 \%$ \\
\hline 4. & 12 & 25 & 300.32 & 300.32 & $0 \%$ \\
\hline 5. & 5 & 5 & 180 & 180 & $0 \%$ \\
\hline & \multicolumn{5}{|c|}{ Rata - Rata Persentase Error } \\
\hline
\end{tabular}

Hasil pengujian menunjukkan bahwa perhitungan manual Fuzzy Tsukamoto dengan hasil perhitungan pada sistem sudah sesuai dengan persentase error $0 \%$.

\subsection{Pengujian Sensor MQ-7}

Pengujian Sensor Gas MQ-7 dilakukan dengan cara membandingkan hasil output kadar gas karbon monoksida dari sensor MQ-7 dengan alat ukur Gas detector UYIGAO UA506 yang hasilnya dapat dilihat pada Tabel 5.

Tabel 5. Pengujian Sensor MQ-7

\begin{tabular}{|c|c|c|c|c|}
\hline No. & $\begin{array}{c}\text { Sensor } \\
\text { MQ-135 }\end{array}$ & $\begin{array}{c}\text { UYIGAO } \\
\text { UA506 }\end{array}$ & Selisih & $\begin{array}{c}\text { Persentase } \\
\text { Error }\end{array}$ \\
\hline 1. & $0.01 \mathrm{ppm}$ & $0.014 \mathrm{ppm}$ & $0.004 \mathrm{ppm}$ & $28.57 \%$ \\
\hline 2. & $0.02 \mathrm{ppm}$ & $0.026 \mathrm{ppm}$ & $0.006 \mathrm{ppm}$ & $23.07 \%$ \\
\hline 3. & $0.03 \mathrm{ppm}$ & $0.033 \mathrm{ppm}$ & $0.003 \mathrm{ppm}$ & $9.09 \%$ \\
\hline 4. & $0.02 \mathrm{ppm}$ & $0.024 \mathrm{ppm}$ & $0.004 \mathrm{ppm}$ & $16.66 \%$ \\
\hline 5. & $0.05 \mathrm{ppm}$ & $0.061 \mathrm{ppm}$ & $0.011 \mathrm{ppm}$ & $18.03 \%$ \\
\hline \multicolumn{4}{|c|}{ Rata-rata persentase error } & $19.08 \%$ \\
\hline
\end{tabular}

Dari hasil pengujian pada tabel 5 yang dilakukan pada ruangan tertutup pada malam hari bisa diamati bahwa selisih terbesar pada pengujian yaitu sebesar $0.08 \mathrm{ppm}$ dan selisih terkecil yaitu 
$0.04 \mathrm{ppm}$ dengan rata -rata persentase error sebesar $6.54 \%$.

\subsection{Pengujian MQ-135}

Pengujian Sensor Gas MQ-135 dilakukan dengan cara membandingkan hasil output kadar gas Amonia dari sensor MQ-135 dengan alat ukur Gas detector UYIGAO UA506 yang hasilnya bisa dilihat pada Tabel 6.

Tabel 6. Pengujian Sensor MQ-135 Amonia

\begin{tabular}{|c|c|c|c|c|}
\hline No. & $\begin{array}{c}\text { Sensor } \\
\text { MQ-135 }\end{array}$ & $\begin{array}{c}\text { UYIGAO } \\
\text { UA506 }\end{array}$ & Selisih & $\begin{array}{c}\text { Persentase } \\
\text { Error }\end{array}$ \\
\hline 1. & $0.01 \mathrm{ppm}$ & $0.014 \mathrm{ppm}$ & $0.004 \mathrm{ppm}$ & $28.57 \%$ \\
\hline 2. & $0.02 \mathrm{ppm}$ & $0.026 \mathrm{ppm}$ & $0.006 \mathrm{ppm}$ & $23.07 \%$ \\
\hline 3. & $0.03 \mathrm{ppm}$ & $0.033 \mathrm{ppm}$ & $0.003 \mathrm{ppm}$ & $9.09 \%$ \\
\hline 4. & $0.02 \mathrm{ppm}$ & $0.024 \mathrm{ppm}$ & $0.004 \mathrm{ppm}$ & $16.66 \%$ \\
\hline 5. & $0.05 \mathrm{ppm}$ & $0.061 \mathrm{ppm}$ & $0.011 \mathrm{ppm}$ & $18.03 \%$ \\
\hline & \multicolumn{4}{|c|}{ Rata-rata persentase error } \\
\hline
\end{tabular}

Lalu dilanjutkan Pengujian Sensor Gas MQ-135 dilakukan dengan cara membandingkan hasil output kadar gas Karbon dioksida dari sensor MQ-135 dengan alat ukur CO2 Meter yang hasilnya bisa dilihat padaTabel 7 .

Tabel 7. Pengujian Sensor MQ-135 CO2

\begin{tabular}{|c|c|c|c|c|}
\hline No. & $\begin{array}{c}\text { Sensor MQ- } \\
135\end{array}$ & CO2 Meter & Selisih & Persentase Error \\
\hline 1. & $125 \mathrm{ppm}$ & $131 \mathrm{ppm}$ & $6 \mathrm{ppm}$ & $4.5 \%$ \\
\hline 2. & $118 \mathrm{ppm}$ & $125 \mathrm{ppm}$ & $7 \mathrm{ppm}$ & $5.6 \%$ \\
\hline 3. & $216 \mathrm{ppm}$ & $223 \mathrm{ppm}$ & $7 \mathrm{ppm}$ & $3.13 \%$ \\
\hline 4. & $304 \mathrm{ppm}$ & $312 \mathrm{ppm}$ & $8 \mathrm{ppm}$ & $2.5 \%$ \\
\hline 5. & $334 \mathrm{ppm}$ & $342 \mathrm{ppm}$ & $8 \mathrm{ppm}$ & $2.33 \%$ \\
\hline & \multicolumn{3}{|c|}{ Rata - rata persentase error } & $3.16 \%$ \\
\hline
\end{tabular}

Hasilnya rata-rata error pada deteksi amonia yaitu sebesar $19.08 \%$ dan pada deteksi karbon dioksida sebesar $3.16 \%$

\subsection{Pengujian Sensor Ultrasonic}

Pengujian Sensor Ultrasonic dilakukan dengan cara membandingkan hasil output dari sensor Ultrasonic dengan alat ukur penggaris yang bisa dilihat pada Tabel 8 .

Tabel 8. Pengujian Sensor Ultrasonic

\begin{tabular}{|l|c|c|c|c|}
\hline No. & Penggaris & $\begin{array}{c}\text { Sensor } \\
\text { Ultrasonic }\end{array}$ & Selisih & $\begin{array}{c}\text { Persentase } \\
\text { Error }\end{array}$ \\
\hline 1. & $5 \mathrm{~cm}$ & $5,57 \mathrm{~cm}$ & $0,57 \mathrm{~cm}$ & $11,4 \%$ \\
\hline 2. & $10 \mathrm{~cm}$ & $11,24 \mathrm{~cm}$ & $1,04 \mathrm{~cm}$ & $10,4 \%$ \\
\hline 3. & $15 \mathrm{~cm}$ & $16,95 \mathrm{~cm}$ & $1,95 \mathrm{~cm}$ & $13 \%$ \\
\hline 4. & $24 \mathrm{~cm}$ & $25,79 \mathrm{~cm}$ & $1,79 \mathrm{~cm}$ & $7,45 \%$ \\
\hline 5. & $33 \mathrm{~cm}$ & $35,28 \mathrm{~cm}$ & $2,28 \mathrm{~cm}$ & $6,9 \%$ \\
\hline \multicolumn{5}{|c|}{ Rata - rata persentase error } \\
\hline
\end{tabular}

Hasilnya yaitu selisih terbesar yaitu $2,28 \mathrm{~cm}$ dan selisih terkecil yaitu $0,57 \mathrm{~cm}$ dengan rata - rata persentase error $9,83 \%$.

\subsection{Pengujian Flame Sensor}

Pengujian Flame Sensor dilakukan dengan cara melihat reaksi dan sensitifitas dari Flame Sensor jika mendeteksi api pada jarak tertentu. Pengujian dilakukan dengan cara mendeteksi api pada korek api pada jarak tertentu yang diukur dengan penggaris yang hasilnya dapat dilihat pada Tabel 9 .

Tabel 9. Pengujian flame sensor

\begin{tabular}{|l|c|c|c|c|}
\hline No. & $\begin{array}{c}\text { Jarak Api dengan } \\
\text { Sensor }\end{array}$ & $\begin{array}{c}\text { Analog } \\
\text { Value }\end{array}$ & $\begin{array}{c}\text { Nilai } \\
\text { Voltage }\end{array}$ & Status Api \\
\hline 1. & $5 \mathrm{~cm}$ & 78 & $0.38 \mathrm{v}$ & Terdeteksi \\
\hline 2. & $20 \mathrm{~cm}$ & 92 & $0.44 \mathrm{v}$ & Terdeteksi \\
\hline 3. & $40 \mathrm{~cm}$ & 148 & $0.77 \mathrm{v}$ & Terdeteksi \\
\hline 4. & $60 \mathrm{~cm}$ & 206 & $1.00 \mathrm{v}$ & Terdeteksi \\
\hline 5. & $80 \mathrm{~cm}$ & 357 & $1.74 \mathrm{v}$ & Terdeteksi \\
\hline 6. & $84 \mathrm{~cm}$ & 382 & $2,03 \mathrm{v}$ & $\begin{array}{c}\text { Tidak } \\
\text { Terdeteksi }\end{array}$ \\
\hline
\end{tabular}

Dari tabel diatas apat diamati bahwa jarak optimal terjauh flame sensor untuk mendeteksi api dari korek api dalam ruangan yang terang yaitu sejauh $80 \mathrm{~cm}$ dengan nilai voltage $1.74 \mathrm{v}$ dan pada jarak $84 \mathrm{~cm}$ api sudah tidak terdeteksi lagi.

\subsection{Pengujian Limit Switch}

Pengujian Limit Switch dilakukan dengan cara melihat sensitifitas dan kesesuaian output dari Limit Switch jika trigger tertekan dan tidak. Output yang dihasilkan telah sesuaiy ang hasilnya bisa dilihat pada Tabel 10.

Tabel 10. Pengujian limit switch

\begin{tabular}{|l|c|c|c|c|}
\hline No. & $\begin{array}{c}\text { Kondisi Trigger } \\
\text { Limit Swith }\end{array}$ & Value & Output & $\begin{array}{c}\text { Kondisi } \\
\text { Sesuai }\end{array}$ \\
\hline 1. & Tidak Tertekan & HIGH & - & $\checkmark$ \\
\hline 2. & $\begin{array}{c}\text { Setengah Tertekan/ } \\
\text { Tertekan sebagian }\end{array}$ & HIGH & - & $\checkmark$ \\
\hline 3. & Tertekan & LOW & $\begin{array}{c}\text { Diam Selama 2 } \\
\text { detik lalu membuat } \\
\text { motor mundur } \\
\text { selama 2 detik }\end{array}$ & $\checkmark$ \\
\hline
\end{tabular}

\subsection{Pengujian Motor Servo}

Pengujian Motor Servo dilakukan dengan cara membandingkan hasil output dari pergerakan motor servo dengan alat ukur penggaris busur guna mengetahui satuan derajat sudut. Hasilnya bisa dilihat pada Tabel 11 .

Tabel 11. Pengujian motor servo

\begin{tabular}{|l|l|l|l|}
\hline No. & Sudut pada Servo & Sudut Pada Busur & $\begin{array}{c}\text { Persentase } \\
\text { Error }\end{array}$ \\
\hline 1. & $0^{\circ}$ & $0^{\circ}$ & $0 \%$ \\
\hline 2. & $90^{\circ}$ & $89^{\circ}$ & $1.12 \%$ \\
\hline 3. & $180^{\circ}$ & $178^{\circ}$ & $1.12 \%$ \\
\hline
\end{tabular}

\subsection{Pengujian Modul ESP8266}

Pengujian pada modul ESP8266 atau disebut juga modul wifi ini menggunakan pengujian 
pengiriman data dari sensor Ke web server.Hasilnya bisa dilihat pada Tabel 12 .

Tabel 12. Pengujian modul esp8266

\begin{tabular}{|l|c|c|c|c|c|c|}
\hline \multirow{2}{*}{ No. } & Delay yang & \multicolumn{5}{|c|}{ Tampil di web pada pengiriman Ke- } \\
\cline { 3 - 7 } & diatur (detik) & 1 & 2 & 3 & 4 & 5 \\
\hline 1. & 50 & 50 detik & 51 detik & 50 detik & 50 detik & 50 detik \\
\hline 2. & 30 & 30 detik & 30 detik & 30 detik & 31 detik & 31 detik \\
\hline 3. & 20 & 21 detik & 20 detik & 22 detik & 20 detik & 20 detik \\
\hline 4. & 10 & 15 detik & 16 detik & 14 detik & 30 detik & 16 detik \\
\hline 5 & 5 & 22 detik & 61 detik & 58 detik & 43 detik & 15 detik \\
\hline
\end{tabular}

Dari tabel 12 diamati bahwa delay terkecil dan terstabil adalah pada pengaturan delay 20 detik dengan selisih 2 detik pada pengiriman ke 3 . Sedangkan untuk delay paling tidak stabil yaitu 5 detik dengan selisih terbesar hingga 56 detik pada pengiriman data ke 2 .

\subsection{Pengujian NodeMCU}

Pengujian pada NodeMCU dilakukan dengan cara menerima data dari website dengan metode GET lalu dieksekusi. Hasil pengujian dapat dilihat pada Tabel 13.

Tabel 13. Pengujian NodeMCU

\begin{tabular}{|l|c|c|c|c|c|c|}
\hline \multirow{2}{*}{ No. } & \multirow{2}{*}{$\begin{array}{c}\text { Delay yang } \\
\text { diatur } \\
\text { (milisecond) }\end{array}$} & \multicolumn{5}{|c|}{ Respon komponen pada pengiriman Ke- } \\
\cline { 3 - 7 } & 1 & 2 & 3 & 4 & 5 \\
\hline 1. & 20 & $20 \mathrm{~ms}$ & $20 \mathrm{~ms}$ & $20 \mathrm{~ms}$ & $20 \mathrm{~ms}$ & $20 \mathrm{~ms}$ \\
\hline 2. & 10 & $10 \mathrm{~ms}$ & $10 \mathrm{~ms}$ & $10 \mathrm{~ms}$ & $10 \mathrm{~ms}$ & $10 \mathrm{~ms}$ \\
\hline 3. & 5 & $5 \mathrm{~ms}$ & $5 \mathrm{~ms}$ & $5 \mathrm{~ms}$ & $7 \mathrm{~ms}$ & $5 \mathrm{~ms}$ \\
\hline 4. & 3 & $6 \mathrm{~ms}$ & $6 \mathrm{~ms}$ & $13 \mathrm{~ms}$ & $6 \mathrm{~ms}$ & $5 \mathrm{~ms}$ \\
\hline 5 & 1 & $10 \mathrm{~ms}$ & $9 \mathrm{~ms}$ & $9 \mathrm{~ms}$ & $15 \mathrm{~ms}$ & $11 \mathrm{~ms}$ \\
\hline
\end{tabular}

Dari tabel 13. diamati bahwa respon tercepat dan stabil node mcu untuk mengeksekusi perintah yaitu sebesar $5 \mathrm{~ms}$. Sementara untuk delay dibawah $5 \mathrm{~ms}$ cenderung tidak dengan selisih terbesar $14 \mathrm{~ms}$ dari delay yang ditetapkan.

\subsection{Pengujian Robot SAR}

Pengujian semua sistem pada robot sar dilakukan dengan melakukan pengujian pada semua kinerja sistem yang ada baik kinerja komponen maupun kinerja dan eksekusi program yang telah dibuat. Bentuk robot dapat dilihat pada Gambar 9.

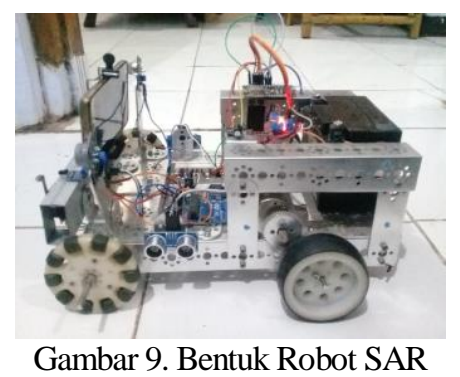

Pengujian pada fungsionalitas komponen pada robot SAR yang bisa dilihat pada Tabel 14 .
Tabel 14. Pengujian Fungsionalitas Robot SAR

\begin{tabular}{|c|c|c|c|c|c|}
\hline No. & Nama Komponen & $\begin{array}{c}\text { Jum } \\
\text { lah }\end{array}$ & $\begin{array}{l}\text { Arus yang } \\
\text { dibutuhkan }\end{array}$ & $\begin{array}{c}\text { Berfungsi } \\
\text { dengan } \\
\text { baik }\end{array}$ & $\begin{array}{c}\text { Mempunya } \\
\text { i kendala / } \\
\text { trouble }\end{array}$ \\
\hline 1. & $\begin{array}{l}\text { Sensor MQ-7 (Deteksi } \\
\text { Kadar Gas Karbon } \\
\text { Monoksida) }\end{array}$ & 1 & $0,015 \mathrm{~A}$ & $\checkmark$ & $\mathrm{x}$ \\
\hline 2. & $\begin{array}{c}\text { Sensor MQ-135 } \\
\text { (Deteksi Kadar Gas } \\
\text { Amonia \& Karbon } \\
\text { Diolssida) }\end{array}$ & 1 & $0,015 \mathrm{~A}$ & $\checkmark$ & $\mathrm{x}$ \\
\hline 3. & $\begin{array}{l}\text { Sensor Ultrasonic } \\
\text { (Deteksi Jarak) }\end{array}$ & 2 & $0,015 \mathrm{~A}$ & $\checkmark$ & $\mathrm{x}$ \\
\hline 4. & $\begin{array}{c}\text { Flame Sensor (Deteksi } \\
\text { Api) }\end{array}$ & 1 & $0,02 \mathrm{~A}$ & $\checkmark$ & $\mathrm{x}$ \\
\hline 5. & Arduino Uno R3 & 1 & $0,36 \mathrm{~A}$ & $\checkmark$ & $\mathrm{x}$ \\
\hline 6. & Modul ESP8266 & 1 & $0,01 \mathrm{~A}$ & $\checkmark$ & $\mathrm{x}$ \\
\hline 7. & Limit Switch & 2 & $0,01 \mathrm{~A}$ & $\sqrt{ }$ & $\mathrm{x}$ \\
\hline 8. & Motor Servo & 1 & $0,02 \mathrm{~A}$ & $\checkmark$ & $\mathrm{x}$ \\
\hline 9. & Driver Motor L298N & 1 & $2 \mathrm{~A}$ & $\checkmark$ & $\mathrm{X}$ \\
\hline 8. & Motor DC $12 \mathrm{~V}$ & 2 & $3,2 \mathrm{~A}$ & $\checkmark$ & $\mathrm{X}$ \\
\hline 9. & NodeMCU & 1 & $0,17 \mathrm{~A}$ & $\checkmark$ & $\mathrm{x}$ \\
\hline 10. & Kamera HP & 1 & - & $\checkmark$ & $\mathrm{x}$ \\
\hline & \multicolumn{4}{|c|}{ Total Arus yang dibutuhkan } & $5,835 \mathrm{~A}$ \\
\hline
\end{tabular}

Keterangan :

- $\checkmark$ : Iya $\quad \cdot X$ : Tidak.

Dari pertimbangan diatas, maka waktu pemakaian Robot SAR dapat diperoleh dari perhitungan sebagai berikut.

Jika :

Jumlah Arus $=5,835 \mathrm{~A}$

Aki yang digunakan $=12 \mathrm{~V} 5 \mathrm{Ah} / 10 \mathrm{Hr}$

Maka :

$\mathrm{I}=5,835 \mathrm{~A}$

Waktu Pemakaian $=5 \mathrm{Ah} / 5,835 \mathrm{~A}$

$=0,85 \mathrm{Jam}$-dieffisiensi Aki sebesar $20 \%$

$=0,85 \mathrm{jam}-0.17 \mathrm{jam}$

$=0,68$ jam (40 Menit)

Jadi dapat disimpulkan bahwa robot SAR dapat beroperasi optimal selama 40 Menit.

\subsection{Tampilan Halaman Utama}

Halaman Utama digunakan untuk memonitoring semua sensor pada robot, serta tampilan dari kamera secara realtime juga tempat untuk mengontrol robot lewat keyboard dan fungsi mengambil foto pada kamera. Tampilan halaman Utama bisa dilihat pada Gambar 10.

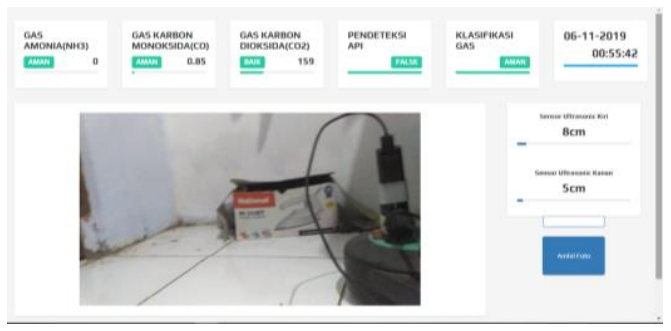

Gambar 10. Tampilan halaman utama 


\subsection{Tampilan Halaman Data}

Pada halaman data ditampilkan riwayat data gas amonia, karbon monoksida, karbon dioksida, flame sensor, hasil defuzzifikasi, klasifikasi, serta waktu dan data pengambilan data. Juga terdapat button untuk menghapus data pada tab data. Kemudian di tab foto terdapat daftar dan tampilan foto dari kamera robot yang telah diambil sebelumnya. Tampilan Halaman data bisa dilihat pada Gambar 11.

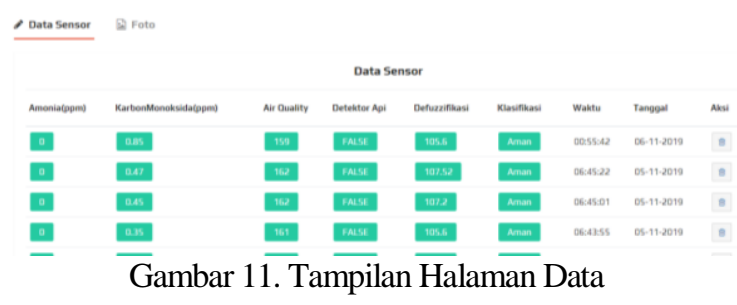

\subsection{Tampilan Halaman Grafik}

Pada halaman grafik disajikan 3 data grafik dari perbandingan kadar NH3 dan CO, Sensor Ultrasonic kanan dan kiri, Serta kandungan CO. Tampilan halaman Grafik bisa dilihat pada Gambar 12.

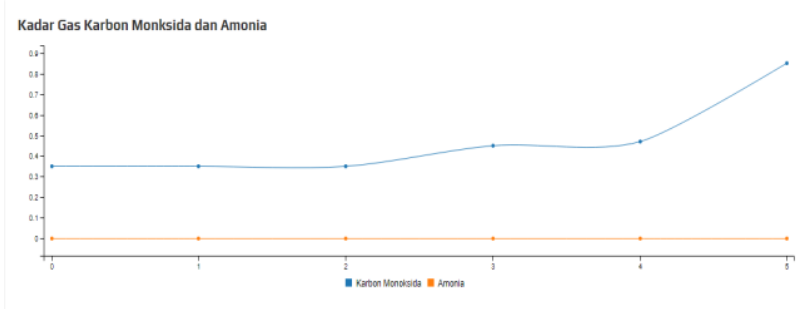

Gambar 12. Tampilan Halaman Grafik

\subsection{Pengujian Kompatibilitas Browser}

Pengujian software pada penelitian ini dengan dilakukannya menguji kompabilitas website terhadap web browser Hasil uji coba kompabilitas website terhadap web browser seperti ditunjukan pada Tabel 16.

Tabel 16. Pengujian kompatibilitas browser

\begin{tabular}{|l|l|c|c|c|}
\hline \multirow{2}{*}{ No. } & \multicolumn{1}{|c|}{ Aspek Pengujian } & \multicolumn{3}{|c|}{ Web Browser } \\
\cline { 3 - 5 } & \multicolumn{1}{|c|}{$\begin{array}{l}\text { Mozila } \\
\mathbf{( 4 7 . 0 . 2 )}\end{array}$} & $\begin{array}{l}\text { Chrome } \\
\mathbf{( 7 8 . 0 . 3 )}\end{array}$ & $\begin{array}{l}\text { Microsoft } \\
\text { Edge (44.1.0) }\end{array}$ \\
\hline 1. & Panel Sensor Pada halaman Utama & $\checkmark$ & $\checkmark$ & $\checkmark$ \\
\hline 2. & $\begin{array}{l}\text { Tampilan data sensor dan bar data } \\
\text { pada halaman utama }\end{array}$ & $\checkmark$ & $\checkmark$ & $\checkmark$ \\
\hline 3. & Fungsi Kontrol pada halaman utama & $\checkmark$ & $\checkmark$ & $\checkmark$ \\
\hline 4. & $\begin{array}{l}\text { Tampilan kamera pada halaman } \\
\text { utama }\end{array}$ & $\checkmark$ & $\checkmark$ & $\checkmark$ \\
\hline 5. & $\begin{array}{l}\text { Fungsi ambil foto pada halaman } \\
\text { utama }\end{array}$ & $\checkmark$ & $\checkmark$ & $\checkmark$ \\
\hline 6. & $\begin{array}{l}\text { Tampilan data dan css pada halaman } \\
\text { data }\end{array}$ & $\checkmark$ & $\checkmark$ & $\checkmark$ \\
\hline 7. & $\begin{array}{l}\text { Tampilan Foto dan fungsi hapus } \\
\text { pada halaman data }\end{array}$ & $\checkmark$ & $\checkmark$ & $\checkmark$ \\
\hline 8. & $\begin{array}{l}\text { Tampilan responsif pada halaman } \\
\text { grafik }\end{array}$ & $\checkmark$ & $\checkmark$ & $\checkmark$ \\
\hline
\end{tabular}

Keterangan :

- $\checkmark$ : Berhasil $\quad$ x : Tidak Berhasil.
Dapat dilihat hasil uji coba pada tabel 4.1 bahwa aplikasi yang dibuat dapat berjalan dengan baik pada web browser Mozila Firefox (47.0.2), Google Chrome (78.0.3) dan Microsoft Edge (44.1.0) yaitu semua fungsi di halaman utama seperti panel data sensor, fungsi input kontrol, tombol foto, dan tampilan kamera hingga grafik yang responsif di halaman grafik karena aplikasi merupakan website responsive yang dibuat menggunakan pemrograman PHP.

\section{KESIMPULAN DAN SARAN}

Dari beberapa tahap pengujian dan perbandingan yang telah dilakukan, menghasilkan beberapa kesimpulan diantaranya :

1 Dari hasil pengujian sensor diketahui memiliki rata-rata persentase error pada sensor MQ-7 sebesar 6.54\%, Sensor MQ-135 sebesar 19.08\% untuk deteksi gas Amonia dan 3.16\% untuk Karbon Dioksida, serta 9,83\% untuk sensor ultrasonic.

2 Jarak terjauh flame sensor untuk mendeteksi api secara optimal yaitu pada jarak $80 \mathrm{~cm}$ dengan nilai tegangan $1.74 \mathrm{v}$ dan tidak dapat lagi mendeteksi api pada jarak $84 \mathrm{~cm}$ dengan nilai tegangan $2.03 \mathrm{v}$.

3 Robot SAR dapat beroperasi optimal selama 40 Menit.

4 Website berjalan dengan baik pada beberapa web browser yang diujikan yaitu Mozila Firefox (47.0.2), Google Chrome (78.0.3) dan Microsoft Edge (44.1.0) karena aplikasi merupakan website responsive yang dibuat menggunakan PHP.

5 Metode Fuzzy Tsukamoto dapat berjalan dengan baik dan akurat pada sistem.

\section{DAFTAR PUSTAKA}

[1] Dedy Irawan, J., Handoko, F. and Adriantatri, E., 2019. Ruang Kuliah Pintar Pemantau Tingkat Efektivitas Pembelajaran Yang Dapat Mendeteksi Mahasiswa Bosan Dan Mengantuk. In Seminar Nasional Inovasi dan Aplikasi Teknologi di Industri.

[2] Liandy, A., 2018. RANCANG BANGUN PEMANTAUAN GAS BERBAHAYA DAN SUHU PADA RUANGAN MELALUI WEBSITE BERBASIS ARDUINO (Doctoral dissertation, Institut Teknologi Nasional Malang).

[3] Kusumadewi, S. and Purnomo, H., 2010. Aplikasi Logika Fuzzy untuk pendukung keputusan. Yogyakarta: Graha Ilmu, pp.33-34.

[4] Luthfi, M. M. 2016, July 17. Mari Mengenal Apa itu Internet ofThing (IoT). Retrieved November 29, 2018, from https://idcloudhost.com/mari-mengenal-apaitu-internet-thingiot/. 
[5] Sibagariang, K.W., 2016. Perancangan Sistem Pengukur Detak Jantung Secara Jarak Jauh Berbasis Atmega 8535 Dengan Tampilan PC.

[6] Hidayah, A.N., Triyanto, D. and Brianorman, Y., PERANCANGAN ALAT UKUR GAS KARBON MONOKSIDA (CO) BERBASIS PESAWAT TANPA AWAK. Coding Jurnal Komputer dan Aplikasi, 2(1).

[7] Sebayang, M.A., Stasiun Pemantau Kualitas Udara Berbasis Web Web Based Quality Air
Monitor

Station. Telecommunication

Engineering, 1(1), pp.24-33.

[8] Hariadi, D., 2016. Aplikasi Pengukur Tinggi Badan Digital Atmega328 Berbasis Arduino Nano dengan Sensor Ultrasonik di The Clinic Medan.

[9] Putra, N.D., 2018. WIRELESS SMART TAG DEVICE SEBAGAI SISTEM KEAMANAN RUMAH BERBASIS IoT. 